\title{
MILK PRODUCTION EFFICIENCY OF FRIESIAN COWS FED DIFFERENT LEVELS OF SEAWEEDS AND ALGAE
}

\author{
T.I. El- Monayer, K.E.I. Etman, H.M. El-Nahas and G.F. Shahin \\ Animal Production Research Institute, Agricultural Research Center, Dokki, Giza, \\ Egypt
}

\section{SUMMARY}

Twenty five lactating Friesian cows averaged $520 \mathrm{~kg}$ live body weight were assigned to evaluate the effect of supplementation of lactating Friesian cows with two levels from seaweed (dietary supplements) and algae (water supplements) on milk production efficiency. Cows were divided equally into five experimental groups and fed the same basal ration but differed in feed additives. Cows in the $1^{\text {st }}$ group (TI) were fed a basal ration containing concentrate feed mixture (CFM), berseem and rice straw (control). Cows in the $2^{\text {nd }}$ (T2) and $3^{\text {rd }}$ (T3) groups were fed the basal ration supplemented with 50 and $100 \mathrm{~g}$ seaweed/h/d, respectively. While, those in the $4^{\text {th }}$ (T4) and $5^{\text {th }}$ (T5) groups were fed the basal ration which treated with 5 and $10 \mathrm{ml}$ algae/h/d, respectively. Feeding period lasted for 145 days. One digestibility trial using 15 lactating Friesian cows, three in each group was conducted to determine nutrient digestibility coefficients and feeding values. Rumen and blood parameters, feed utilization and economic efficiency were also studied. Results showed that cows fed rations supplemented with both levels of seaweed or algae improved $(P<0.05)$ most nutrient digestibility coefficients and feeding values as total digestible nutrients $(T D N)$, digestible crude protein (DCP) or starch value (SV) as well as rumen and blood parameters. Milk yield as a actual milk yield, 4\% fat corrected milk, total yields of fat and protein in milk, feed efficiency and economic efficiency were the highest $(P<0.05)$ for cows in T4.

In the light of the present study, greater beneficial effects on the performance of lactating cows were found with improved economic efficiency of milk production, especially those treated with $5 \mathrm{ml}$ Algae/h/d was detected .

Keywords: Friesian cows, seaweed, algae, digestibility, milk yield, blood

\section{INTRODUCTION}

Increasing the human population all over the world requires continues supply of food from either plant or animal sources. In Egypt, many investigations were carried out to increase animal performance to meet the increasing demands of population by using some dietary additives or supplements in animal feeding.

Seaweeds are plentiful to increase animal production in many areas of the world, but most research works indicated that it is not good source of either energy or protein and it should be used as mainly as mineral supplement. It contain about $2 \%$ $\mathrm{Ca}, 0.4-0.5 \% \mathrm{P}$ and being a good source of Fe and extremely high in I. Algae is an

Issued by The Egyptian Society of Animal Production 
attractive possibility as a protein source, except for the high moisture content. In this respect, preliminary results of cultivated fresh water algae indicated that it contained about $50 \%$ protein, $6-7 \%$ fiber, $4-6 \%$ fat and $6 \%$ ash (Church and Pond, 1988).

Mineral contents of seaweeds according to Mehany et al. (2003) were $1.5 \% \mathrm{Ca}$, $1.05 \% \mathrm{P}, 3.2 \% \mathrm{Na}, 1.5 \mathrm{Cl}, 2.5 \% \mathrm{~K}, 0.75 \% \mathrm{Mg}, 9.5$ p.p.m Cu, 10 p.p.m Co, $0.10 \% \mathrm{Fe}$, $0.08 \%$ I, 5 p.p.m Mn and 65 p.p.m $\mathrm{Zn}$ resulting beneficial effects on digestibility coefficient of most nutrients and growth performance of growing calves. However, the information on its effect on milk production efficiency of dairy cows are scare.

The objective of this study was to investigate the effect of supplementation with two levels from each of seaweed and algae on nutrient digestibility coefficients, rumen and blood parameters as well as milk production efficiency of Friesian cows.

\section{MATERIALS AND METHODS}

This study was carried out at Karada Experimental Station, Animal Production Research Institute, Agricultural Research Center, Ministry of Agriculture during the period from 2006.

\section{Animals and experimental rations}

Total of 25 lactating Friesian cows averaged $520 \mathrm{~kg}$ live body weight and ranged between second and fourth lactating period were used in this study. All experimental cows were fed a basal ration, which contained concentrate feed mixture (CFM), Egyptian berseem (EB) and rice straw (RS) at rates of about $50 \%, 40 \%$, and $10 \%$ on DM basis, respectively, according to the allowance of NRC (1988) for dairy cattle. The CFM contained $42 \%$ undecorticated cotton seed meal, $10 \%$ wheat bran, $30 \%$ yellow corn, $10 \%$ rice bran, 5\% Molasses, $2 \%$ limestone and $1 \%$ common salt. Chemical analysis of different ingredient feed stuffs and calculated chemical composition of the basal ration are presented in Table (1).

Table 1. Chemical analysis of different feed stuffs and calculated chemical composition of the basal ration

\begin{tabular}{lccccccc}
\hline \multirow{2}{*}{ Item } & \multirow{2}{*}{ DM\% } & \multicolumn{6}{c}{ Chemical composition on DM basis (\%) } \\
\cline { 3 - 8 } & & CP & EE & CF & NFE & OM & Ash \\
\hline Feed stuff: & & & & & & & \\
CFM & 90.72 & 17.45 & 3.25 & 14.22 & 54.86 & 89.78 & 10.22 \\
Egyptian berseem & 15.40 & 16.10 & 3.20 & 24.50 & 44.85 & 88.65 & 11.35 \\
Rice straw & 90.48 & 3.76 & 1.37 & 35.55 & 40.82 & 81.56 & 18.50 \\
Basal ration & 100 & 15.27 & 3.01 & 20.91 & 49.15 & 88.34 & 11.66 \\
\hline
\end{tabular}

* Chemical analysis according to AOAC (1985).

$\mathrm{DM}=$ dry matter, $\mathrm{CP}=$ crude protein, $\mathrm{EE}=$ ether extract, $\mathrm{CF}=$ crude fiber, $\mathrm{NFE}=$ nitrogen free extract, $\mathrm{OM}=$ organic matter

The experimental animals were divided into 5 similar groups according to live body weight, milk production and reproductive status. In the $1^{\text {st }}$ group, animals were fed the basal ration without any supplements and were considered as a control group (T1). However, animals in the other tested groups were fed the control ration supplemented with $50 \mathrm{~g} / \mathrm{h} / \mathrm{d}(\mathrm{T} 2)$ and $100 \mathrm{~g} / \mathrm{h} / \mathrm{d}$ (T3) from seaweed or treated with 5 $\mathrm{ml} / \mathrm{h} / \mathrm{d}$ (T4) or $10 \mathrm{ml} / \mathrm{h} / \mathrm{d}$ (T5) from algae in small mount of drinking water before 
drinking. The offered seaweed was in a form of Kelp meal (Ascophyllum nodosum) which manufactured by Acadian seaplants Limited which exported by the Gold Company in Egypt. On the other hand, the commercial name of the offered Algae is biobolem which contain $5 \mathrm{~g}$ sodium Algaenate/Litre

Throughout feeding period of 145 days, rations of all groups were adjusted biweekly according to changes in LBW and milk production. Rations were offered twice daily at 9 a.m. and 5 p.m., while fresh water was offered free before and after milking.

\section{Digestibility trials}

Five digestibility trials were conducted using 3 animals from each group to determine the digestion coefficient and nutritive value of the experimental rations using Acid Insoluble Ash (AIA) method (Van Kaulen and Young, 1977). Feces were collected quantitively for each of the three cows. Feces samples $(5 \%$ of the daily feces) were individually collected, dried, grinded and kept for chemical analyses.

\section{Experimental procedures}

All experimental cows were completely machine- milked twice daily at 8.0 a.m. and 4.0 p.m. Daily milk yield was individually recorded and actual milk yield was corrected to $4 \%$ fat corrected milk $(4 \% \mathrm{FCM})$ according to the formula of Gaines (1923). Milk samples were individually taken biweekly from evening and morning consecutive milking and kept in deep freezer for chemical analysis. Milk energy was calculated using the formula given by Overman and Sanmann (1926).

Cows were weighed biweekly at the early morning before feeding or water drink. Milk production efficiency was calculated as the amount of DM, DCP or TDN required to produce either one $\mathrm{kg}$ milk or fat corrected milk (FCM). Economic feed efficiency (EE \%) was calculated as the ratio between the price of milk yield and cost of feeding.

\section{Blood samples}

Blood samples were withdrawn from the jugular vein of cows in each group during the digestibility trials after 3 hours from feeding. Serum was separated from the whole blood by centrifugation and kept it in frozen at $-20^{\circ} \mathrm{C}$ for chemical analysis to dertermine some blood biochemicals including concentration of total protein (Cornall et al. 1949), albumin (Doumas et al., 1971) and triglycerides (Dryer, 1970) as well as concentration of thyroid hormones (triiodothyronine, $\mathrm{T}_{3}$ and thyroxine, $\mathrm{T}_{4}$ ) according to Gruhm et al. (1987). While, globulin concentration was determined by differences between total protein and albumin concentration.

\section{Rumen liquor samples}

Rumen liquor samples were taken from three cows in each group before morning feeding and at 3 hours post feeding at the end of the feeding period. Each sample was strained through four folds of gauze and divided into two portions, one for immediate $\mathrm{pH}$ value (digital $\mathrm{pH}$ meter) and the second portion was preserved to determine the concentration of total volatile fatty acids (TVFA) and ammonia- $\mathrm{N}$ $\left(\mathrm{NH}_{3}-\mathrm{N}\right)$ in rumen liquor. About two milliliters of each strained rumen liquor sample was fixed with $2 \mathrm{ml} \mathrm{HCl}(0.1 \mathrm{~N})$ and $1.0 \mathrm{ml}$ orthophosphoric to determine TVFA 
concentration as described by Abou-Akkada and El-Shazly (1964) While, concentration of $\mathrm{NH}_{3}-\mathrm{N}$ was determined according to Conway (1978).

\section{Statistical analysis}

Data were analyzed using the computer programme of statistical analysis system (SAS, 1982). The significant differences among means were determined by Duncan's Multiple-Range Test (Duncan, 1955).

\section{RESULTS AND DISCUSSION}

\section{Digestion coefficients and feeding values}

The digestion coefficients of all nutrients and feeding values of all experimental rations are presented in Table (2). Results showed that all treatments significantly $(\mathrm{P}<0.05)$ increased digestion coefficients of $\mathrm{DM}$ as compared to the control (T1), except for T5. It is of interest to note that, both seaweed treatments (T2 \& T3) significantly $(\mathrm{P}<0.05)$ increased $\mathrm{CP}$ digestibility and decreased $\mathrm{CF}$ digestibility, while both Algae treatments (T4 \& T5) showed an opposite trend as compared to the control treatment. However, all treatments significantly $(\mathrm{P}<0.05)$ decreased digestibility coefficients of NFE, increased digestibility coefficients of EE and did not affect digestibility coefficients of $\mathrm{OM}$ as compared to control ration (T1) as shown in table (2). In agreement with the present results, dietary supplementation of seaweed had beneficial effects on digestibility coefficient of most nutrients of growing calves (Mehany et al., 2003).

Table 2. Digestion coefficients and nutritive values of different experimental groups

\begin{tabular}{|c|c|c|c|c|c|}
\hline Item & $\begin{array}{c}\mathrm{T} 1 \\
\text { (control) }\end{array}$ & $\begin{array}{c}\mathrm{T2} \\
(50 \mathrm{SW})\end{array}$ & $\begin{array}{c}\text { T3 } \\
(100 \mathrm{SW})\end{array}$ & $\begin{array}{c}\text { T4 } \\
\text { (5 Algae) }\end{array}$ & $\begin{array}{c}\text { T5 } \\
\text { (10 Algae) }\end{array}$ \\
\hline DM intake $(\mathrm{kg})$ & 19.79 & 20.55 & 19.41 & 19.03 & 20.16 \\
\hline \multicolumn{6}{|c|}{ Digestion Coefficient (\%): } \\
\hline DM & $72.26^{\mathrm{b}}$ & $75.57^{\mathrm{a}}$ & $74.68^{\mathrm{a}}$ & $75.22^{\mathrm{a}}$ & $73.15^{\mathrm{b}}$ \\
\hline $\mathrm{CP}$ & $70.71^{\mathrm{b}}$ & $72.98^{\mathrm{a}}$ & $72.76^{\mathrm{a}}$ & $69.78^{\mathrm{b}}$ & $71.53^{\mathrm{b}}$ \\
\hline $\mathrm{EE}$ & $78.75^{\mathrm{b}}$ & $88.28^{\mathrm{a}}$ & $85.79^{\mathrm{a}}$ & $87.17^{\mathrm{a}}$ & $86.21^{\mathrm{a}}$ \\
\hline $\mathrm{CF}$ & $62.06^{\mathrm{a}}$ & $61.26^{\mathrm{b}}$ & $60.31^{\mathrm{b}}$ & $62.93^{\mathrm{a}}$ & $62.72^{\mathrm{a}}$ \\
\hline NFE & $53.32^{\mathrm{a}}$ & $52.21^{\mathrm{b}}$ & $52.55^{\mathrm{b}}$ & $52.69^{\mathrm{b}}$ & $52.08^{\mathrm{b}}$ \\
\hline OM & $79.16^{\mathrm{a}}$ & $79.32^{\mathrm{a}}$ & $78.88^{\mathrm{a}}$ & $79.13^{\mathrm{a}}$ & $79.00^{\mathrm{a}}$ \\
\hline \multicolumn{6}{|c|}{ Nutritive value (\%): } \\
\hline TDN & $54.87^{\mathrm{b}}$ & $55.07^{\mathrm{a}}$ & $54.89^{\mathrm{b}}$ & $55.17^{\mathrm{a}}$ & $55.02^{\mathrm{a}}$ \\
\hline SV & $47.81^{\mathrm{b}}$ & $48.69^{\mathrm{a}}$ & $48.33^{\mathrm{a}}$ & $48.74^{\mathrm{a}}$ & $48.51^{\mathrm{a}}$ \\
\hline DCP & $10.79^{\mathrm{b}}$ & $11.14^{\mathrm{a}}$ & $11.11^{\mathrm{a}}$ & $10.66^{\mathrm{b}}$ & $10.92^{\mathrm{a}}$ \\
\hline \multicolumn{6}{|c|}{$\begin{array}{l}\text { a and b: Means denoted within the same row with different superscripts are significantly } \\
\text { different at } \mathrm{P}<0.05 \text {. } \\
\mathrm{T} 1=\text { Control ration, } \mathrm{T} 2=\text { Control ration supplemented with } 50 \mathrm{~g} \text { seaweed } / \mathrm{h} / \mathrm{d}, \mathrm{T} 3=\text { Control } \\
\text { ration supplemented with } 100 \mathrm{~g} \text { seaweed } / \mathrm{h} / \mathrm{d} \text {, T4= Control ration plus } 5 \mathrm{ml} \text { algae } \backslash \mathrm{h} \backslash \mathrm{d} \text { in } \\
\text { drinking water and } \mathrm{T} 5=\text { Control ration plus } 10 \mathrm{ml} \text { algaelh } \backslash \mathrm{d} \text { in drinking water. } \mathrm{SW}=\text { seaweed }\end{array}$} \\
\hline
\end{tabular}

Such trend in nutrient digestibility coefficients was reflected in different figures of nutritive values as TDN, SV and DCP in treatments, being the highest significantly 
$(\mathrm{P}<0.05)$ of TDN and SV was recorded in T4 $(5 \mathrm{ml} \mathrm{Algae} / \mathrm{h} / \mathrm{d})$, followed by T2 $(50 \mathrm{~g}$ $\mathrm{SW} / \mathrm{h} / \mathrm{d}$ ), which appeared to have the highest DCP\% (Table 2). Digestibility coefficients and nutritive value of tested rations were similar to those reported by Hamada (1989).

\section{Rumen liquor parameters}

Results presented in Table (3) revealed that ruminal $\mathrm{pH}$ value significantly $(\mathrm{P}<0.05)$ increased only in T3 before feeding and in both T3 and T5 at $3 \mathrm{~h}$ postfeeding while significantly $(\mathrm{P}<0.05)$ decreased in $\mathrm{T} 2, \mathrm{~T} 3$ and $\mathrm{T} 4$ at $6 \mathrm{~h}$ post- feeding comparing with the control group (T1). Generally, $\mathrm{pH}$ values of all treatment groups decreased at $3 \mathrm{~h}$ post feeding, then increased at $6 \mathrm{~h}$ post-feeding with Algae treatment and control groups only.

Table 3. Rumen liquor parameters of lactating cows in different experimental groups

\begin{tabular}{|c|c|c|c|c|c|}
\hline Item & $\begin{array}{c}\mathrm{T} 1 \\
\text { (control) }\end{array}$ & $\begin{array}{c}\text { T2 } \\
(50 \mathrm{SW})\end{array}$ & $\begin{array}{c}\text { T3 } \\
(100 S W)\end{array}$ & $\begin{array}{c}\text { T4 } \\
\text { (5 Algae) }\end{array}$ & $\begin{array}{c}\text { T5 } \\
\text { (10 Algae) }\end{array}$ \\
\hline \multicolumn{6}{|l|}{ pH value: } \\
\hline Before feeding & $7.63^{\mathrm{b}}$ & $7.63^{\mathrm{b}}$ & $8.21^{\mathrm{a}}$ & $7.53^{\mathrm{b}}$ & $7.64^{\mathrm{b}}$ \\
\hline $3 \mathrm{~h}$ post feeding & $6.66^{\mathrm{b}}$ & $6.73^{\mathrm{ab}}$ & $6.89^{\mathrm{a}}$ & $6.49^{\mathrm{b}}$ & $6.98^{\mathrm{a}}$ \\
\hline $6 \mathrm{~h}$ post feeding & $7.02^{\mathrm{a}}$ & $6.55^{\mathrm{b}}$ & $6.77^{\mathrm{b}}$ & $6.62^{\mathrm{b}}$ & $6.99^{\mathrm{a}}$ \\
\hline \multicolumn{6}{|c|}{ Concentration of total VFA $(\mathrm{meq} / 100 \mathrm{ml})$ : } \\
\hline Before feeding & $4.50^{\mathrm{b}}$ & $4.40^{\mathrm{b}}$ & $4.40^{\mathrm{b}}$ & $4.90^{\mathrm{a}}$ & $4.00^{\mathrm{b}}$ \\
\hline $3 \mathrm{~h}$ post feeding & $6.70^{\mathrm{b}}$ & $7.60^{\mathrm{a}}$ & $6.60^{\mathrm{b}}$ & $6.96^{\mathrm{ab}}$ & $6.10^{\mathrm{b}}$ \\
\hline $6 \mathrm{~h}$ post feeding & $11.50^{\mathrm{b}}$ & $13.55^{\mathrm{a}}$ & $12.60^{\mathrm{b}}$ & $14.40^{\mathrm{a}}$ & $12.20^{\mathrm{b}}$ \\
\hline \multicolumn{6}{|c|}{ Concentration of ammonia-N $(\mathrm{mg} / 100 \mathrm{ml})$ : } \\
\hline Before feeding & $12.60^{\mathrm{b}}$ & $11.60^{\mathrm{b}}$ & $19.20^{\mathrm{a}}$ & $12.80^{\mathrm{b}}$ & $14.10^{\mathrm{b}}$ \\
\hline $3 \mathrm{~h}$ post feeding & $20.10^{\mathrm{ab}}$ & $19.70^{\mathrm{b}}$ & $22.49^{\mathrm{a}}$ & $20.60^{\mathrm{ab}}$ & $21.00^{\mathrm{ab}}$ \\
\hline $6 \mathrm{~h}$ post feeding & $16.40^{\mathrm{b}}$ & $19.10^{\mathrm{a}}$ & $19.30^{\mathrm{a}}$ & $17.20^{\mathrm{b}}$ & $17.30^{\mathrm{b}}$ \\
\hline \multicolumn{6}{|c|}{$\begin{array}{l}\text { a , b: Means denoted within the same row with different superscripts are significantly different } \\
\text { at } \mathrm{P}<0.05 \text {. } \\
\mathrm{SW}=\text { seaweed, VFA= volitale fatty acid }\end{array}$} \\
\hline $\begin{array}{l}\text { Total VFA's } \\
\text { before feeding, } \\
\text { Generally, Total } \\
\text { post feeding tim } \\
\text { than between bef } \\
\text { Concentratiol } \\
\text { both before feed } \\
\text { other hand, all p } \\
\text { h post feeding ( } \\
\text { It is worthy } \mathrm{r} \\
\text { from } 5 \text { to } 10 \mathrm{~m} \\
\text { decreased total } \\
\text { were reported by }\end{array}$ & $\begin{array}{l}\text { centration } \\
\mathrm{T} 2 \text { at } 3 \mathrm{~h} \\
\mathrm{~A} \text { 's concen } \\
\text { ut the rate c } \\
\text { feeding an } \\
\mathrm{NH}_{3}-\mathrm{N} \text { in } \\
3 \mathrm{~h}-6 \mathrm{~h} \mathrm{p} \\
\text { alues in all } \\
\text { e } 3 \text { ). } \\
\text { ng that incr } \\
\text { opeared to } \\
\text { 's concent }\end{array}$ & $\begin{array}{l}\text { rumen liqu } \\
\text { st-feeding } \\
\text { tion in all } \\
\text { increase ws } \\
\mathrm{h} \text { post-fee } \\
\text { men liquor } \\
\text { feeding a } \\
\text { eatment gr } \\
\text { sing seawe } \\
\text { crease pH } \\
\text { ion at all s }\end{array}$ & $\begin{array}{l}\text { r significan } \\
\text { ind in T2 } \\
\text { eatment gr } \\
\text { higher bet } \\
\text { ing (Table } \\
\text { ignificantly } \\
\text { compared } \\
\text { aps showed } \\
\text { d level fror } \\
\text { alue and c } \\
\text { mpling tim }\end{array}$ & $\begin{array}{l}(\mathrm{P}<0.05) \text { ir } \\
\mathrm{d} \mathrm{T} 4 \text { at } 6 \mathrm{~h} \\
\text { ps increased } \\
\text { en } 3 \text { and } 6 \\
\text { the control } \\
\text { enerally lov } \\
50 \text { to } 100 \mathrm{~g} \\
\text { centration } \\
\text { (Table 5). }\end{array}$ & $\begin{array}{l}\text { reased in T4 } \\
\text { ost-feeding. } \\
\text { y advancing } \\
\text { post-feeding } \\
\text { ased in } \mathrm{T} 3 \text { at } \\
\mathrm{T} 1 \text { ). On the } \\
\mathrm{r} \text { values at } 6 \\
\mathrm{r} \text { algae level } \\
\mathrm{NH}_{3}-\mathrm{N} \text { and } \\
\text { milar results }\end{array}$ \\
\hline
\end{tabular}




\section{Blood biochemicals and thyroid hormones}

Results in Table (4) revealed that concentration of total proteins significantly $(\mathrm{P}<0.05)$ increased by low level of SW (T2) and high level of Algae (T5). This increase was associated with significant $(\mathrm{P}<0.05)$ increase in albumin concentration with T2 and not significant with T3, T4 and T5. But T5 showed significant $(\mathrm{P}<0.05)$ increase in globulin concentration. However, the high level of SW (T3) or low level of Algae (T4) did not affect concentration of total proteins or their fractions and did not differ significantly than in T1, T2 and T5. Such trends were reflected in nearly similar AL/GL ratios in all treatments.

Table 4. Concentration of some biochemicals and thyroid hormones in blood serum of lactating cows in experimental groups

\begin{tabular}{|c|c|c|c|c|c|}
\hline Item & $\begin{array}{c}\text { T1 } \\
\text { (control) }\end{array}$ & $\begin{array}{c}\mathrm{T2} \\
(50 \mathrm{SW}) \\
\end{array}$ & $\begin{array}{c}\text { T3 } \\
(100 \mathrm{SW})\end{array}$ & $\begin{array}{c}\text { T4 } \\
\text { (5 Algae) }\end{array}$ & $\begin{array}{c}\text { T5 } \\
\text { (10 Algae) }\end{array}$ \\
\hline \multicolumn{6}{|c|}{ Serum biochemicals: } \\
\hline $\begin{array}{l}\text { Total protein } \\
(\mathrm{g} / \mathrm{dl})\end{array}$ & $8.28^{\mathrm{b}}$ & $8.82^{\mathrm{a}}$ & $8.63^{\mathrm{ab}}$ & $8.71^{\mathrm{ab}}$ & $8.80^{\mathrm{a}}$ \\
\hline Albumin $(\mathrm{g} / \mathrm{dl})$ & $4.28^{\mathrm{b}}$ & $4.78^{\mathrm{a}}$ & $4.52^{\mathrm{ab}}$ & $4.58^{\mathrm{ab}}$ & $4.45^{\mathrm{b}}$ \\
\hline Globulin $(\mathrm{g} / \mathrm{dl})$ & $4.00^{\mathrm{b}}$ & $4.04^{\mathrm{b}}$ & $4.11^{\mathrm{ab}}$ & $4.13^{\mathrm{ab}}$ & $4.35^{\mathrm{a}}$ \\
\hline $\mathrm{AL} / \mathrm{GL}$ ratio & 1.07 & 1.18 & 1.10 & 1.11 & 1.05 \\
\hline $\begin{array}{l}\text { Triglycerides } \\
(\mathrm{mg} / \mathrm{dl})\end{array}$ & $115.87^{\mathrm{b}}$ & $123.06^{\mathrm{a}}$ & $120.09^{\mathrm{ab}}$ & $126.60^{\mathrm{a}}$ & $119.98^{\mathrm{b}}$ \\
\hline \multicolumn{6}{|c|}{ Thyroid gland hormones (ng/dl): } \\
\hline $\mathrm{T}_{3}$ & $102.49^{\mathrm{b}}$ & $112.28^{\mathrm{a}}$ & $105.10^{\mathrm{b}}$ & $109.18^{\mathrm{a}}$ & $104.87^{\mathrm{b}}$ \\
\hline $\mathrm{T}_{4}$ & $2.27^{\mathrm{b}}$ & $2.75^{\mathrm{a}}$ & $2.42^{\mathrm{b}}$ & $2.71^{\mathrm{a}}$ & $2.61^{\mathrm{ab}}$ \\
\hline
\end{tabular}

It is of interest to note that concentration of triglycerides and thyroid hormones (T3 and T4) appeared the same trend of total proteins concentration, significantly $(\mathrm{P}<0.05)$, being the highest with low level of SW (Table 4). This agreed with the results of Lee et al. (2005). Also, the observed increase in most biochemicals studied and thyroid hormones in T2 might be attributed to the recorded highest nutritive values as TDN, SV and DCP for T2 (Table 2).

\section{Milk production \\ Milk yield}

Results presented in Table (5) showed that the ration containing either low or high SW level (T2 and T3) and high Algae level did not affect milk production, while level of $5 \mathrm{ml}$ algae $(\mathrm{T} 4)$ significantly $(\mathrm{P}<0.05)$ appeared the highest milk yield as actual (AMY) and 4\% FCM milk yield by about 24 and $32 \%$ compared to the control, respectively. Interestingly to observe that the recorded improvement in milk yield may be attributed to improving concentration of total proteins and triglycerides as well as thyroid hormones as metabolic hormones in blood serum of cows in T4 as shown in Table (4). Similar results regard to milk yield were reported by Nikil' Burskii (1991), Tolokonnikov et al. (1992), Risheng and Changlin (1998), Baek et al. (2004) and Lee et al. (2005). 
The most important finding in the present study point of view was that both SW levels significantly $(\mathrm{P}<0.05)$ increased in percentages of fat and protein in milk rather than increasing milk yield as AMY of 4\% FCM (Table 5). However, when milk composition was expressed as daily yields, cows in $\mathrm{T} 4$ showed significantly $(\mathrm{P}<0.05)$ the highest yields from fat, protein, lactose, total solids and solids not fat

Table 5. Milk yield and composition of cows in experimental groups

\begin{tabular}{|c|c|c|c|c|c|}
\hline Item & $\begin{array}{c}\mathrm{T} 1 \\
\text { (control) }\end{array}$ & $\begin{array}{c}\mathrm{T} 2 \\
(50 \mathrm{SW})\end{array}$ & $\begin{array}{c}\text { T3 } \\
(100 \mathrm{SW})\end{array}$ & $\begin{array}{c}\text { T4 } \\
\text { (5 Algae) }\end{array}$ & $\begin{array}{c}\text { T5 } \\
\text { (10 Algae) }\end{array}$ \\
\hline \multicolumn{6}{|c|}{ Average daily milk yield (kg): } \\
\hline Actual milk & $14.90^{\mathrm{b}}$ & $15.22^{\mathrm{b}}$ & $15.60^{\mathrm{b}}$ & $18.43^{\mathrm{a}}$ & $14.97^{\mathrm{b}}$ \\
\hline $4 \%$ FCM & $13.02^{\mathrm{b}}$ & $14.54^{\mathrm{b}}$ & $14.78^{\mathrm{b}}$ & $17.21^{\mathrm{a}}$ & $13.58^{\mathrm{b}}$ \\
\hline \multicolumn{6}{|c|}{ Milk composition (\%): } \\
\hline Fat & $3.13^{\mathrm{b}}$ & $3.70^{\mathrm{a}}$ & $3.65^{\mathrm{a}}$ & $3.56^{\mathrm{b}}$ & $3.38^{\mathrm{b}}$ \\
\hline Protein & $2.34^{\mathrm{b}}$ & $2.43^{\mathrm{a}}$ & $2.46^{\mathrm{a}}$ & $2.38^{\mathrm{b}}$ & $2.35^{\mathrm{b}}$ \\
\hline Lactose & $4.39^{\mathrm{a}}$ & $4.16^{\mathrm{b}}$ & $4.29^{\mathrm{ab}}$ & $4.31^{\mathrm{ab}}$ & $4.35^{\mathrm{a}}$ \\
\hline Total solids & $10.60^{\mathrm{b}}$ & $10.90^{\mathrm{a}}$ & $10.82^{\mathrm{ab}}$ & $10.92^{\mathrm{a}}$ & $10.69^{\mathrm{b}}$ \\
\hline Solids not fat & $7.47^{\mathrm{a}}$ & $7.20^{\mathrm{b}}$ & $7.17^{\mathrm{b}}$ & $7.36^{\mathrm{a}}$ & $7.31^{\mathrm{ab}}$ \\
\hline \multicolumn{6}{|c|}{ Daily yield (g): } \\
\hline Fat & $466.37^{\mathrm{b}}$ & $563.14^{\mathrm{ab}}$ & $569.40^{\mathrm{ab}}$ & $656.11^{\mathrm{a}}$ & $505.99^{\mathrm{b}}$ \\
\hline Protein & $348.66^{\mathrm{b}}$ & $369.85^{\mathrm{b}}$ & $383.76^{\mathrm{ab}}$ & $438.63^{\mathrm{a}}$ & $351.80^{\mathrm{b}}$ \\
\hline Lactose & $654.11^{\mathrm{b}}$ & $633.15^{b}$ & $669.24^{\mathrm{b}}$ & $794.33^{\mathrm{a}}$ & $651.20^{\mathrm{b}}$ \\
\hline Total solids & $1579.40^{\mathrm{b}}$ & $1659.98^{\mathrm{b}}$ & $1687.92^{b}$ & $2012.56^{\mathrm{a}}$ & $1600.29^{b}$ \\
\hline Solids not fat & $1113.0^{\mathrm{b}}$ & $1095.84^{b}$ & $1118.52^{b}$ & $1356.45^{\mathrm{a}}$ & $1094.3^{b}$ \\
\hline Energy (kcal) & $650.29^{\mathrm{b}}$ & $716.01^{\mathrm{a}}$ & $710.25^{\mathrm{a}}$ & $699.87^{\mathrm{ab}}$ & $679.12^{b}$ \\
\hline
\end{tabular}

The present results indicated pronounced effect of $5 \mathrm{ml} \backslash \mathrm{h} \backslash \mathrm{d}$ Algae (T4) on increasing milk yield (AMY and 4\% FCM) and in turn total yield of all milk components, while SW increased only milk composition in term of percentages of fat and proteins in milk. The obtained results are in agreement with those reported by Nikil' Burskii (1991), Tolokonnikov et al. (1992) and Papadopoulos et al. (2002).

\section{Feed utilization and economic efficiency}

Feed efficiency expressed as $\mathrm{kg} \mathrm{DM}, \mathrm{TDN}, \mathrm{SV}$ and DCP intake required to give one $\mathrm{kg}$ AMY or $4 \% \mathrm{FCM}$ (Table 6). At the same time the feed efficiency can be calculated with respect to TND or DCP. From these results, cows in T4 fed diet supplemented with $5 \mathrm{ml}$ Algae showed the best feed efficiency as DM, TDN, SV and DCP for kg milk production as AMY or 4\% FCM, while cows in T2 and T5 showed the poorest feed efficiency as compared to the control cows (T1). Such trend was attributed to the lowest total DM intake and the highest milk yields in T4 and T3, while the opposite was obtained for T2 and T5. 
Table 6. Feed utilization and economic efficiency of lactating cows in different experimental groups

\begin{tabular}{|c|c|c|c|c|c|}
\hline Item & $\begin{array}{c}\text { T1 } \\
\text { (Control) }\end{array}$ & $\begin{array}{c}\text { T2 } \\
(50 \mathrm{SW})\end{array}$ & $\begin{array}{c}\text { T3 } \\
(100 \mathrm{SW})\end{array}$ & $\begin{array}{c}\text { T4 } \\
\text { (5 Algae) }\end{array}$ & $\begin{array}{c}\text { T5 } \\
\text { (10 Algae) }\end{array}$ \\
\hline Average LBW & 520 & 540 & 510 & 500 & 530 \\
\hline \multicolumn{6}{|l|}{ Feed intake $(\mathrm{kg})$ as fed: } \\
\hline CFM & 10.40 & 10.80 & 10.20 & 10.00 & 10.60 \\
\hline Berseem & 52.00 & 54.00 & 51.00 & 50.00 & 53.00 \\
\hline Rice straw & 2.600 & 2.70 & 2.55 & 2.50 & 2.65 \\
\hline \multicolumn{6}{|l|}{ DM intake $(\mathrm{Kg})$ : } \\
\hline CFM & 9.43 & 9.79 & 9.25 & 9.07 & 9.61 \\
\hline Berseem & 8.01 & 8.32 & 7.85 & 7.70 & 8.16 \\
\hline Rice straw & 2.35 & 2.44 & 2.31 & 2.26 & 2.39 \\
\hline Total & 19.79 & 20.55 & 19.41 & 19.03 & 20.16 \\
\hline \multicolumn{6}{|l|}{ Daily milk yield (kg): } \\
\hline Actual-milk-yield (AMY) & 14.90 & 15.22 & 15.60 & 18.43 & 14.97 \\
\hline $4 \% \mathrm{FCM}$ & 13.02 & 14.54 & 14.78 & 17.21 & 13.58 \\
\hline \multicolumn{6}{|c|}{ Average daily feed intake (kg): } \\
\hline Total DM & 19.79 & 20.55 & 19.41 & 19.03 & 20.16 \\
\hline TDN & 10.86 & 11.32 & 10.65 & 10.50 & 11.09 \\
\hline SV & 9.46 & 10.01 & 9.38 & 9.28 & 9.78 \\
\hline DCP & 2.05 & 2.19 & 2.07 & 1.94 & 2.11 \\
\hline \multicolumn{6}{|l|}{ Feed efficiency: } \\
\hline $\mathrm{Kg} \mathrm{DM} / \mathrm{kg}$ AMY & 1.33 & 1.35 & 1.24 & 1.03 & 1.35 \\
\hline $\mathrm{Kg} \mathrm{DM} / \mathrm{kg} 4 \% \mathrm{FCM}$ & 1.52 & 1.41 & 1.31 & 1.11 & 1.49 \\
\hline $\mathrm{Kg}$ TDN/kg AMY & 0.729 & 0.744 & 0.683 & 0.569 & 0.741 \\
\hline $\mathrm{Kg}$ TDN/kg 4\% FCM & 0.834 & 0.779 & 0.721 & 0.610 & 0.817 \\
\hline $\mathrm{Kg} \mathrm{SV} / \mathrm{kg}$ AMY & 0.635 & 0.658 & 0.601 & 0.504 & 0.653 \\
\hline $\mathrm{Kg} \mathrm{SV} / \mathrm{kg} 4 \% \mathrm{FCM}$ & 0.727 & 0.688 & 0.635 & 0.539 & 0.720 \\
\hline $\mathrm{Kg}$ DCP/kg AMY & 0.138 & 0.144 & 0.133 & 0.105 & 0.141 \\
\hline $\mathrm{Kg} \mathrm{DCP} / \mathrm{kg} 4 \% \mathrm{FCM}$ & 0.157 & 0.151 & 0.140 & 0.113 & 0.155 \\
\hline \multicolumn{6}{|c|}{ Feed cost (L.E.)/kg milk as: } \\
\hline AMY & 1.00 & 1.02 & 0.94 & 0.78 & 1.02 \\
\hline $4 \% \mathrm{FCM}$ & 1.15 & 1.07 & 0.99 & 0.84 & 1.12 \\
\hline \multicolumn{6}{|l|}{ Economic efficiency $(\%)$ : } \\
\hline AMY & 249 & 245 & 266 & 320 & 245 \\
\hline $4 \%$ FCM & 217 & 234 & 252 & 299 & 222 \\
\hline
\end{tabular}

The observed improvement in feed efficiency of cows in T4 and T3 was reflected in significantly $(\mathrm{P}<0.05)$ the cheapest feed cost in $\mathrm{T} 4$ and $\mathrm{T} 3$ as compared to the treatments (T2 and T5) and the control group (T1, Table 6).

Regarding data of feed cost and price of each $\mathrm{kg}$ produced, cows in T4 showed significantly $(\mathrm{P}<0.05)$ the highest economic efficiency as AMY or FCM as compared to the other groups (Table 6). Similar trend was reported by Risheng and Changlin 
(1998). It could be conclude that animals group fed T4 containing 5ml Algae $\backslash h \backslash d$ as supplemented ration tended to have higher feed efficiency and economical efficiency.

\section{REFERENCES}

Abou-Akkada, A.R. and K.EL-Shazly, 1964. Effect of absence of ciliate protozoa from the rumen on microbical activity and growth of lambs Applied microbiology, 12: 384 .

A.O.A.C., 1985. Official Methods of the Association of Official Agriculture chemists.

Baek, I.K, W.J. Maeng, H.G. lee, S.R. Lee, J.K. Ha, S.S. Lee and J.H. Hwang, 2004. Effects of the brown sea weed residues supplementation on in vitro fermentation and milk production and composition of lactating dairy cows. J. Anim. Sci. and Techn., 46(3): 373-386.

Church, D.C. and W.G. Pond, 1988. Basic of animal nutrition and feeding. $3^{\text {rd }}$ Ed., John Wiley \& Sons, Inc., New York, USA.

Conway, E.J., 1978. Microdiffusion Analysis and Volumetric Error. $4^{\text {th }}$ Ed. The McMillian Co., N. Y.

Cornall, A.G; C.J. Badawill and M.M. David, 1949. Determination of serum proteins by means of the buiret reaction. J. Bio Chem. 177: 751.

Doumas, B, W. Wabson and H. Briggs, 1971. Albumin standards and measurements of serum with bromocresol green. Clin. Chem., 31:87.

Dryer, R.L., 1970. In Fundamentals of clincal chemistry. N.W. Tietz, Ed. W. B. Saunders, Phildelphia, P 329.

Duncan, D.B., 1955. Multiple Range and Multiple F-test. Biometrics, 11.1.

Gaines, W.L., 1923. Relation between percentage of fat content and yield of milk. 1correction of milk yield for fat content Agric. Exo. Sta. bull. 245.

Gruhm, J.G, C.P. Barsano and Y. Kumar, 1987. The development of tests of thyroid function. Arch. Pathol. Lab. Med, 111:84.

Hamada, T., 1989. A new supplementary molasses block feed for the ruminant to improve the production efficiency under poor feeding condition. JARQ (Japan Agri. Res. quarterly. 23 (1): 59-64.

Lee, H.G, Z.S. Hong, Z.H. Li, Xa, Cx, X. Jin, M.G. Jin, H.J. Lee, N.J. Choi, T.S. Koh and Y.J. Choi, 2005. Effect of brown seaweed waste suppmlentation on the lactation performance and endocrine physiology of Holstein lactating cows. J. Ami. Sci. \& Tech. 47(4) 573-582.

Mehany, S.B., W.H. Abdel- Malik, K.E.I. Etman and M.F. El-Says, 2003. Effect of Monensin and/or sea weeds as feed additives on performance of Friesian calves, feed utilization and economical efficiency. Egyptian J. Nutrition and feeds. 6 (Special Issue): 1059-1065

National Research Council, 1988. Nutrient Requirements of Dairy cattle. $6^{\text {th }}$ ed. Acad. Sci. Washington, DC.

Nikil' Burskii, N.I., 1991. Laminaria in diets for sheep. ovtsevodstvo. (1): 33

Overman, O.R. and F.P. Sanman, 1926. The energy of milk as related to composition $3^{\text {rd }}$ Agri. Exp. Sta. bull., 282.

Papadopoulos, G; C. Goulas; E. Apostolaski and R. Abril, 2002. Effect of dietary supplements of algae, containing polyunsaturated fatty acids, on milk yield and the composition of milk products in dairy ewes. J. Dairy Res. (69) 357-365. 
Risheng, M. and Changlin, T. 1998. Effects of supplementing kelp meals on milk production in cows. China Dairy cattle (1): 20-22.

S.A.S., Statistical Analysis System, 1982. User's guide: Statistics S.A.S., Inst., Cary, Nc. Releigh.

Tolokonnikov, Yu.A, I.S. Podokopnaya and T.N. Pisarskaya, 1992. Phyllophora in the diet for cows. Zoolekhniya (516):15-17

Van Keulen, J. and B.A. Young, 1977. Evaluation of acid- insoluble- ash as a natural marker in ruminant digestibility studies. J. Anim. Sci., 44:2. 
كفاءة إنتاج اللبن لأبقار الفريزيان المغذاه علي نسب مختلفة من الأعثاب البحرية والطحالب

طارق إبراهيم المنير، كامل عثمان إبراهيم عثمان، حسن محمود النحاس، جمال فاروق شاهين معهج بحوث الإتتاج الحيوانس، مركز البحوث النزاعية، الجيزة، مصر

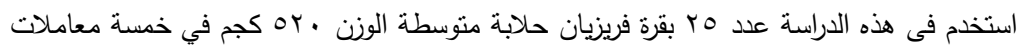

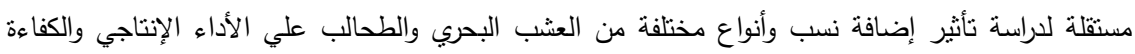
الاقتصادية للأبقار الحلابة واستمرت تجارب التغذية لمدة

$$
\begin{aligned}
& \text { المعاملة (1): علف مركز + برسيم+ثقش ارز ( مجموعة الكنترول) }
\end{aligned}
$$

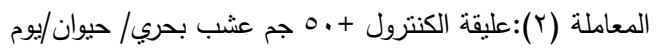

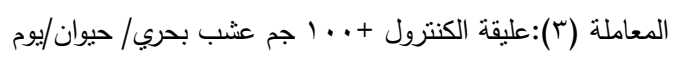

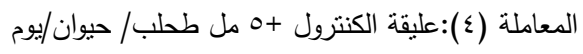

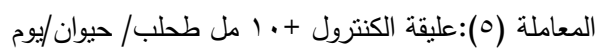

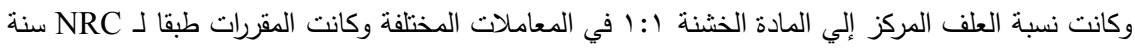

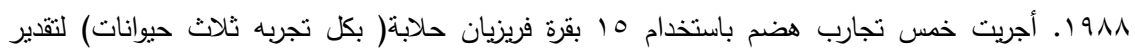

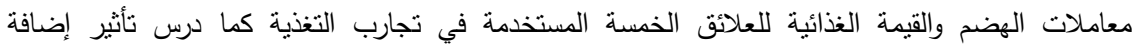

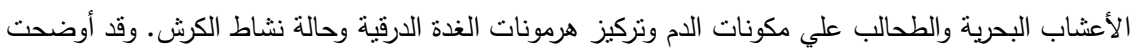

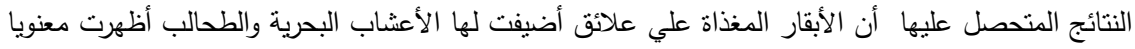

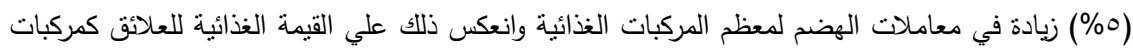

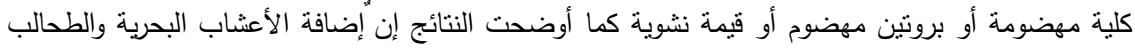

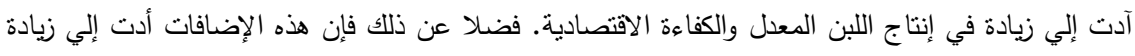

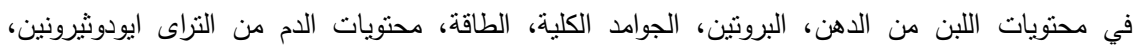
الثيروكسين، البروتين الكلي والجليسريدات.

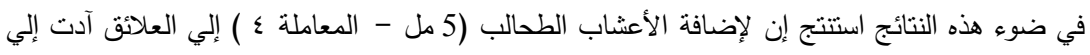

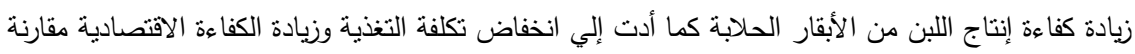

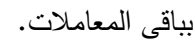

